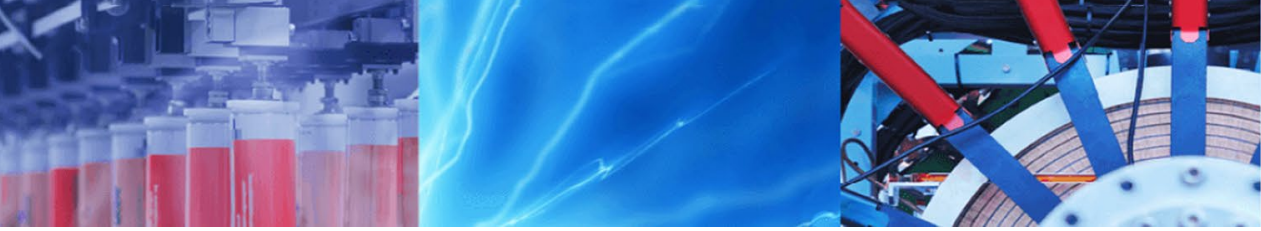

Research Article

\title{
Synthesis and characterization of ring-type and branched polymers including polyethylene glycols by "click" chemistry
}

\author{
Temel Öztürk ${ }^{1} \mathbb{D} \cdot$ Ergül Meyvacı $^{1} \cdot$ Hakan Bektaş $^{1} \cdot$ Emre Menteşe $^{2}$
}

(c) Springer Nature Switzerland AG 2019

\begin{abstract}
Synthesis of ring-type (or branched) polymers including polyethylene glycols was archived via "click" chemistry of 5,6-diazido-2-benzyl-1H-benzimidazole ( $\mathrm{Di}-\mathrm{N}_{3}$ ) [or triazidoacetohydrazide derivative $\left(\mathrm{Tri}^{-} \mathrm{N}_{3}\right)$ ] and terminally dipropargyl polyethylene glycols (PEG-dipropargyl) with different molecular weights. Di- $\mathrm{N}_{3}$ was obtained by reaction of 5,6-dichloro-2-benzyl-1H-benzimidazole ( $\mathrm{Di}$-Cl) and sodium azide. 2-(2-benzyl-5,6-dichloro-1H-benzimidazol-1-yl)- $\mathrm{N}^{\prime}$ (4-chlorobenzylidene)acetohydrazide (Tri-Cl) was synthesized by using Di-Cl. Synthesis of Tri- $\mathrm{N}_{3}$ was archived by means of reaction of Tri-Cl and sodium azide. PEG-dipropargyl was synthesized by using reaction of PEGs with different molecular weights and propargyl chloride. By using Di- $\mathrm{N}_{3}\left(\right.$ or Tri- $\left.\mathrm{N}_{3}\right)$ and PEG-dipropargyl, ring-type (or branched) polymers including polyethylene glycols were synthesized. The polymers were relatively acquired in high yields and low dispersities. The primary parameters for example concentration and time were assessed. The characterization of products was accomplished by using multi instruments such as ${ }^{1} \mathrm{H}-\mathrm{NMR}$, FT-IR, GPC, TGA, DSC, and elemental analysis techniques. The multi instruments studies of the obtained polymers show that the ring-type and branched polymers easily formed as a result of "click" chemistry.
\end{abstract}

Keywords "Click" chemistry · Ring-type polymers · Branched polymers · Polyethylene glycol · Benzimidazole

\section{Introduction}

Sharpless et al. [1] were introduced "click" chemistry technique in literature. "Click" chemistry applications have been available until now [2-15]. Macromolecules are used in technological applications and theoretical studies [16-21]. Polymers based on polyethylene glycol (PEG) are attractive materials for biomedical, industrial, and chemicals applications, as PEG has unparalleled characters such as superior ion absorbability, flexibility, hydrophilicity, and biocompatibility [22-31]. PEG units are helpful for hydrophobic polymers to gain hydrophilicity [32-34]. Benzimidazoles are an important group of heterocyclic compounds in various areas of chemistry and are important intermediates in organic reactions $[35,36]$. They are contained in agrochemicals, dyestuffs, and high-temperature polymer products, and they have interesting biological and pharmaceutical activities [36-40]. Also, some drugs containing benzimidazole nucleus such as albendazole, fenbendazole, oxfenbendazole and thiabendazole, mebendazole are in medical use $[41,42]$. Besides, benzimidazole derivatives can also act as ligands to transition metals for modeling biological systems $[43,44]$. Recently, some metallophthalocyanines ( $\mathrm{Zn}, \mathrm{Ni}, \mathrm{Co}$, and $\mathrm{Cu}$ ) containing benzimidazole ring have been reported with their antibacterial activity [45].

This paper demonstrates synthesis of ringtype and branched polymers including polyethylene glycols using "click" chemistry. In our previous works, we synthesized terminally dipropargyl polyethylene glycol (PEG-dipropargyl) [12],

Temel Öztürk, temel.ozturk@giresun.edu.tr| ${ }^{1}$ Department of Chemistry, Giresun University, 28200 Giresun, Turkey. ${ }^{2}$ Department of Chemistry, Recep Tayyip Erdoğan University, 53100 Rize, Turkey.

SN Applied Sciences (2019) 1:343 | https://doi.org/10.1007/s42452-019-0360-4

Received: 4 February 2019 / Accepted: 11 March 2019 / Published online: 14 March 2019 
<smiles>Clc1cc2nc(Cc3ccccc3)[nH]c2cc1Cl</smiles>

Di-C1<smiles>Nc1cc2nc(Cc3ccccc3)[nH]c2cc1N</smiles>

$\mathrm{Di}-\mathrm{N}_{3}$

Scheme 1 Reaction pathways in the synthesis of Di- $\mathrm{N}_{3}$

5,6-dichloro-2-benzyl-1H-benzimidazole ( $\mathrm{Di}-\mathrm{Cl})$ [46, 47]. In this study, firstly, 2-(2-benzyl-5,6-dichloro- $1 \mathrm{H}$ benzimidazol-1-yl)-N'-(4-chlorobenzylidene)acetohydrazide (Tri-Cl) was obtained by using Di-Cl. 5,6-Diazido2-benzyl-1H-benzimidazole ( $\mathrm{Di}-\mathrm{N}_{3}$ ) was synthesized by chemical reaction of $\mathrm{Di}-\mathrm{Cl}$ with $\mathrm{NaN}_{3}$. In the same way, triazidoacetohydrazide derivative $\left(\right.$ Tri- $\mathrm{N}_{3}$ ) was obtained by chemical interaction of Tri-Cl and with $\mathrm{NaN}_{3}$. Lastly, PEG-dipropargyl and Di- $\mathrm{N}_{3}$ (or Tri- $\mathrm{N}_{3}$ ) were used to obtain the ring-type (or branched) polymers by "click" chemistry. Product characterization is fulfilled in detail.

\section{Experimental}

\subsection{Materials}

$\mathrm{N}, \mathrm{N}$-dimethylformamide (DMF), copper(I) bromide (CuBr), $\mathrm{NaN}_{3}, N, N, N^{\prime}, N^{\prime}, N^{\prime \prime}$-pentamethyldiethylenetriamine (PMDETA), aluminum oxide, and chloroform were supplied by Sigma-Aldrich. Diethyl ether was bought from Carlo Erba Reagent. 4,5-Dichloro-o-phenylenediamine, benzylcyanide and other chemicals were supplied from Merck (Darmstadt, Germany), Aldrich and Fluka (Buchs SG, Switzerland).<smiles>[X][C@H](C)[C@H](C)OC(=O)CBr</smiles>

Di-Cl<smiles>CCOC(=O)Cn1c(Cc2ccccc2)nc2cc(Cl)c(Cl)cc21</smiles><smiles>NNC(=O)Cn1c(Cc2ccccc2)nc2cc(Cl)c(Cl)cc21</smiles><smiles>O=Cc1ccc(Cl)cc1</smiles><smiles>O=C(Cn1c(Cc2ccccc2)nc2cc(Cl)c(Cl)cc21)N/N=C/c1ccc(Cl)cc1</smiles>

Scheme 2 Reaction pathways in the synthesis of Tri-Cl 


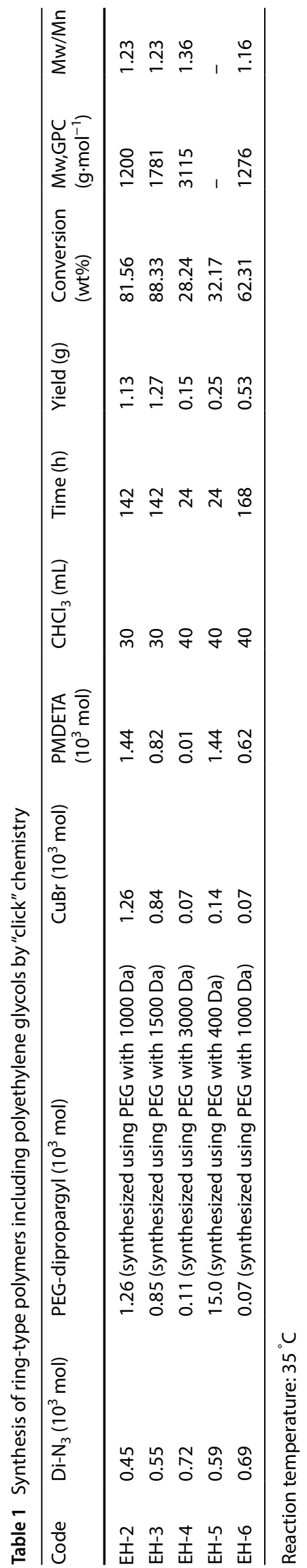

\subsection{Instrumentation}

$\mathrm{Mn}, \mathrm{Mw}$, and dispersities were examined with HPLC/ GPC-Shimadzu RID-10A GPC instrument with tetrahydrofuran mobile phase as the solvent $40{ }^{\circ} \mathrm{C}$ using refractive index detector (RID-10A). A calibration curve was generated with polystyrene standards: $1490 \mathrm{Da}(\mathrm{Mw}), 2500 \mathrm{Da}$ $(\mathrm{Mw}), 5480 \mathrm{Da}(\mathrm{Mw}), 9500 \mathrm{Da}(\mathrm{Mw}), 20,800 \mathrm{Da}(\mathrm{Mw})$, and $53,500 \mathrm{Da}(\mathrm{Mw})$ of low polydispersity. NMR spectra were detected using Bruker Ultra Shield Plus, ultra-long hold time 400 NMR spectrometers. FT-IR spectra were detected using Jasco FT/IR 6600 FT-IR. TGA measurements were conducted using a Seiko II Exstar 6000 model instrument. The sample was heated at a rate of $10^{\circ} \mathrm{C} / \mathrm{min}$ from $25^{\circ} \mathrm{C}$ to $900{ }^{\circ} \mathrm{C}$ under $\mathrm{N}_{2}$. DSC measurements were conducted using a Hitachi DSC 7000 series thermal analysis system. Dried sample was heated at a rate of $10^{\circ} \mathrm{C} / \mathrm{min}$ from -80 to $150^{\circ} \mathrm{C}$ under $\mathrm{N}_{2}$. The elemental analyses of the products were performed by a Costech ECS 4010. PEG-dipropargyl [12] and $\mathrm{Di}-\mathrm{Cl}$ [47] were obtained by literatures.

\subsection{Synthesis of 5,6-Diazido-2-benzyl-1H- benzimidazole $\left(\mathrm{Di}-\mathrm{N}_{3}\right)$}

$1.204 \mathrm{~g}(4.58 \mathrm{mmol})$ of $\mathrm{Di}-\mathrm{Cl}, 2.925 \mathrm{~g}(44.98 \mathrm{mmol})$ of $\mathrm{NaN}_{3}$, and $40 \mathrm{~mL}$ of DMF (as solvent) were put inside a $100 \mathrm{~mL}$ flask $\left([\mathrm{Cl}] /\left[\mathrm{N}_{3}\right]=1 / 5, \mathrm{~mol} / \mathrm{mol}\right)$. The flask was dip in an oil bath fixed at $70^{\circ} \mathrm{C}$ on hot plate. The reaction was performed under $\mathrm{N}_{2}$. After a fixed time, the contents were filtered. DMF was evaporated. The residue was drained into excess diethyl ether to separate $\mathrm{Di}-\mathrm{N}_{3}$. Di- $\mathrm{N}_{3}$ was dried at $25{ }^{\circ} \mathrm{C}$ for $48 \mathrm{~h}$ in vacuum oven. Di- $\mathrm{N}_{3}$ yield was determined gravimetrically. Scheme 1 includes the reaction pathway for the synthesis of Di- $\mathrm{N}_{3}$.

\subsection{Synthesis of 2-(2-Benzyl-5,6-dichloro-1H-b enzimidazol-1-yl)-N'-(4-chlorobenzylidene) acetohydrazide (Tri-Cl)}

A mixture of compound $\mathrm{Di}-\mathrm{Cl}(0.010 \mathrm{~mol})$, ethylbromoacetate $(0.010 \mathrm{~mol})$ and $\mathrm{K}_{2} \mathrm{CO}_{3}(0.025 \mathrm{~mol})$ in acetone $(25 \mathrm{~mL}$ ) was stirred for $10 \mathrm{~h}$ at room temperature. After the completion of the reaction (monitored by TLC), the mixture was poured into water. The precipitate was collected by filtration and recrystallized from acetone-water (1:2) to give pure compound 1 in Scheme 2. To a solution of compound $1(0.010 \mathrm{~mol})$ in ethanol $(20 \mathrm{~mL})$, hydrazine monohydrate $(0.025 \mathrm{~mol})$ was added and was refluxed for $7 \mathrm{~h}$. Then, the mixture was cooled to room temperature. The precipitate was filtered off and washed with ethanol to give pure compound $\mathbf{2}$ in Scheme 2. 4- Chlorobenzaldehyde $(0.01 \mathrm{~mol})$ was added to the solution of 
Table 2 Synthesis of branched polymers including polyethylene glycols by "click" chemistry

\begin{tabular}{|c|c|c|c|c|c|c|c|}
\hline Code & $\operatorname{Tri}^{-N_{3}}\left(10^{3} \mathrm{~mol}\right)$ & PEG-dipropargyl $\left(10^{3} \mathrm{~mol}\right)$ & $\begin{array}{l}\text { PMDETA } \\
\left(10^{3} \mathrm{~mol}\right)\end{array}$ & Yield (g) & $\begin{array}{l}\text { Conversion } \\
\text { (wt\%) }\end{array}$ & $\begin{array}{l}\mathrm{Mw}, \mathrm{GPC} \\
\left(\mathrm{g} \cdot \mathrm{mol}^{-1}\right)\end{array}$ & $\mathrm{Mw} / \mathrm{Mn}$ \\
\hline HAT-1 & 0.59 & 2.53 (synthesized using PEG with $400 \mathrm{Da}$ ) & 1.92 & 0.66 & 50.34 & - & - \\
\hline HAT-2 & 0.51 & 1.98 (synthesized using PEG with $600 \mathrm{Da}$ ) & 1.44 & 0.59 & 40.71 & - & - \\
\hline HAT-3 & 0.53 & 1.01 (synthesized using PEG with $1000 \mathrm{Da}$ ) & 1.92 & 0.95 & 74.71 & 1036 & 1.32 \\
\hline HAT-4 & 0.49 & 0.63 (synthesized using PEG with $1500 \mathrm{Da}$ ) & 1.92 & 0.93 & 77.86 & 1942 & 1.11 \\
\hline HAT-5 & 0.49 & 0.80 (synthesized using PEG with $2000 \mathrm{Da}$ ) & 1.92 & 0.99 & 53.46 & 2194 & 1.18 \\
\hline HAT-6 & 0.51 & 0.55 (synthesized using PEG with $3000 \mathrm{Da}$ ) & 1.92 & 1.13 & 59.25 & 3145 & 1.26 \\
\hline
\end{tabular}

Reaction temperature: $35^{\circ} \mathrm{C}, \mathrm{CHCl}_{3}=8 \mathrm{~mL}, \mathrm{CuBr}=0.07 \times 10^{-3}$ mol, reaction time: $93 \mathrm{~h}$

compound $2(0.01 \mathrm{~mol})$ in ethanol $(20 \mathrm{~mL})$ containing $0.5 \mathrm{~mL}$ of acetic acid and the mixture was refluxed for $7 \mathrm{~h}$. After cooling the mixture to room temperature, a white solid appeared. This crude product was filtrated, dried and recrystallized from ethanol to obtain the pure product Tri-Cl.

\subsection{Synthesis of triazidoacetohydrazide derivative $\left(\right.$ Tri- $\left.\mathrm{N}_{3}\right)$}

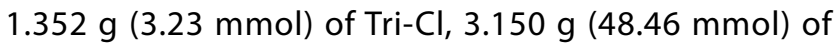
$\mathrm{NaN}_{3}$, and $40 \mathrm{~mL}$ of DMF were put inside a $50 \mathrm{~mL}$ flask $\left([\mathrm{Cl}] /\left[\mathrm{N}_{3}\right]=1 / 5, \mathrm{~mol} / \mathrm{mol}\right)$. The flask was dip in an oil bath fixed at $70{ }^{\circ} \mathrm{C}$ on hot plate. The reaction was performed under $\mathrm{N}_{2}$. After $8 \mathrm{~h}$, the contents were filtered. DMF was evaporated. The residue was drained into excess diethyl ether to separate Tri- $\mathrm{N}_{3}$. Tri- $\mathrm{N}_{3}$ was dried at $25^{\circ} \mathrm{C}$ for $48 \mathrm{~h}$ in vacuum oven. Tri- $\mathrm{N}_{3}$ yield was determined gravimetrically.

\subsection{Synthesis of ring-type and branched polymers including polyethylene glycols via "click" chemistry}

The amounts of chemicals used in the polymerization are shown in Tables 1 and 2. Specified amounts of PEGdipropargyl, $\mathrm{Di}-\mathrm{N}_{3}, \mathrm{CuBr}, \mathrm{PMDETA}$, and chloroform were put separately into a $250 \mathrm{~mL}$ flask followed by injecting $\mathrm{N}_{2}$ for 2 min. The flask was put on a magnetic stirrer at $35^{\circ} \mathrm{C}$. After specific times, the flask contents were filtered. The mixture was drained into diethyl ether to separate precipitated ring-type polymers including polyethylene glycols. Small alumina column was used to remove remaining $\mathrm{CuBr}$ catalyst from copolymer. The polymer was dried at $25^{\circ} \mathrm{C}$ for $48 \mathrm{~h}$ in vacuum oven. The same procedure was fulfilled by using Tri- $\mathrm{N}_{3}$ instead of Di- $\mathrm{N}_{3}$ to synthesize the branched polymers. The polymer yield was detected gravimetrically.

\section{Results and discussion}

\subsection{Synthesis of Di- $\mathrm{N}_{3}$}

Di- $\mathrm{N}_{3}$ was synthesized starting from $\mathrm{Di}-\mathrm{Cl}$. The conversion was $74.10 \mathrm{wt} \%$. The results of elemental analysis of Di- $\mathrm{N}_{3}$ show $42.69 \mathrm{wt} \% \mathrm{C}, 2.83 \mathrm{wt} \% \mathrm{H}$, and $24.74 \mathrm{wt} \% \mathrm{~N}$. The results of elemental analysis agreed with the theoretical values. The ${ }^{1} \mathrm{H}-\mathrm{NMR}$ spectrum of $\mathrm{Di}-\mathrm{N}_{3}$ shown in Fig. 1a displayed peaks at $12.6 \mathrm{ppm}$ for aromatic $-\mathrm{N} \underline{\mathrm{H}}$, $7.8 \mathrm{ppm}$ and $7.3 \mathrm{ppm}$ for aromatic $-\mathrm{C} \underline{\mathrm{H}}, 4.2 \mathrm{ppm}$ for $-\mathrm{CH}_{2}$ linked aromatic groups. The FT-IR spectrum of Di- $\mathrm{N}_{3}$ shown in Fig. 2a indicates signals at $3100 \mathrm{~cm}^{-1}$ for $-\mathrm{NH}, 2770 \mathrm{~cm}^{-1}$ for aliphatic $-\mathrm{CH}_{2}, 2352 \mathrm{~cm}^{-1}$ for $-\mathrm{CN}$, $2109 \mathrm{~cm}^{-1}$ for $-\mathrm{N}_{3}$. The observed peak at $2109 \mathrm{~cm}^{-1}$ for $-\mathrm{N}_{3}$ in the FT-IR spectrum of Di- $\mathrm{N}_{3}$ was further evidence that Di- $\mathrm{N}_{3}$ was obtained.

\subsection{Synthesis of Tri-Cl}

Tri- $\mathrm{Cl}$ was synthesized starting from $\mathrm{Di}-\mathrm{Cl}$. Scheme 2 includes the reaction outline for the synthesis of Tri-Cl. The conversion was $85.13 \mathrm{wt} \%$. The ${ }^{1} \mathrm{H}-\mathrm{NM}$ spectrum of Tri-Cl shown in Fig. $1 \mathrm{~b}$ displayed at $11.8 \mathrm{ppm}$ for $-\mathrm{N} \underline{\mathrm{H}}, 8.2 \mathrm{ppm}$ and $8.0 \mathrm{ppm}$ for $-\mathrm{N}=\mathrm{C} \underline{\mathrm{H}}, 7.9-7.3 \mathrm{ppm}$ for aromatic $-\mathrm{CH}$, $5.5 \mathrm{ppm}$ and $5.1 \mathrm{ppm}$ for $-\mathrm{C}_{2} \mathrm{C}=\mathrm{O}, 4.2 \mathrm{ppm}$ for $-\mathrm{C}_{2}$ linked aromatic group. The FT-IR spectrum of Tri-Cl shown in Fig. $2 b$ indicates signals at $3174 \mathrm{~cm}^{-1}$ for $-\mathrm{NH}, 2954 \mathrm{~cm}^{-1}$ for aliphatic $-\mathrm{CH}_{2}, 2352 \mathrm{~cm}^{-1}$ for $-\mathrm{CN}, 1674 \mathrm{~cm}^{-1}$ for $-\mathrm{C}=\mathrm{O}$.

\subsection{Synthesis of Tri- $\mathrm{N}_{3}$}

Tri- $\mathrm{N}_{3}$ was obtained from Tri-Cl. Scheme 3 includes the reaction pathway for the synthesis of Tri- $\mathrm{N}_{3}$. The conversion was $88.42 \mathrm{wt} \%$. The ${ }^{1} \mathrm{H}-\mathrm{NMR}$ spectrum of Tri- $\mathrm{N}_{3}$ displayed at $12.1 \mathrm{ppm}$ for $-\mathrm{N} \underline{\mathrm{H}}, 8.2 \mathrm{ppm}$ and $8.1 \mathrm{ppm}$ for $-\mathrm{N}=\mathrm{CH}, 8.0-7.2 \mathrm{ppm}$ for aromatic $-\mathrm{CH}, 5.5 \mathrm{ppm}$ and $5.1 \mathrm{ppm}$ for $-\mathrm{C}_{\underline{2}} \mathrm{C}=\mathrm{O}, 4.3 \mathrm{ppm}$ for $-\mathrm{C}_{\underline{2}}$ linked aromatic group. The FT-IR spectrum of Tri- $\mathrm{N}_{3}$ shown in Fig. $2 \mathrm{c}$ indicates signals at $3201 \mathrm{~cm}^{-1}$ for $-\mathrm{NH}, 2900 \mathrm{~cm}^{-1}$ for aliphatic 


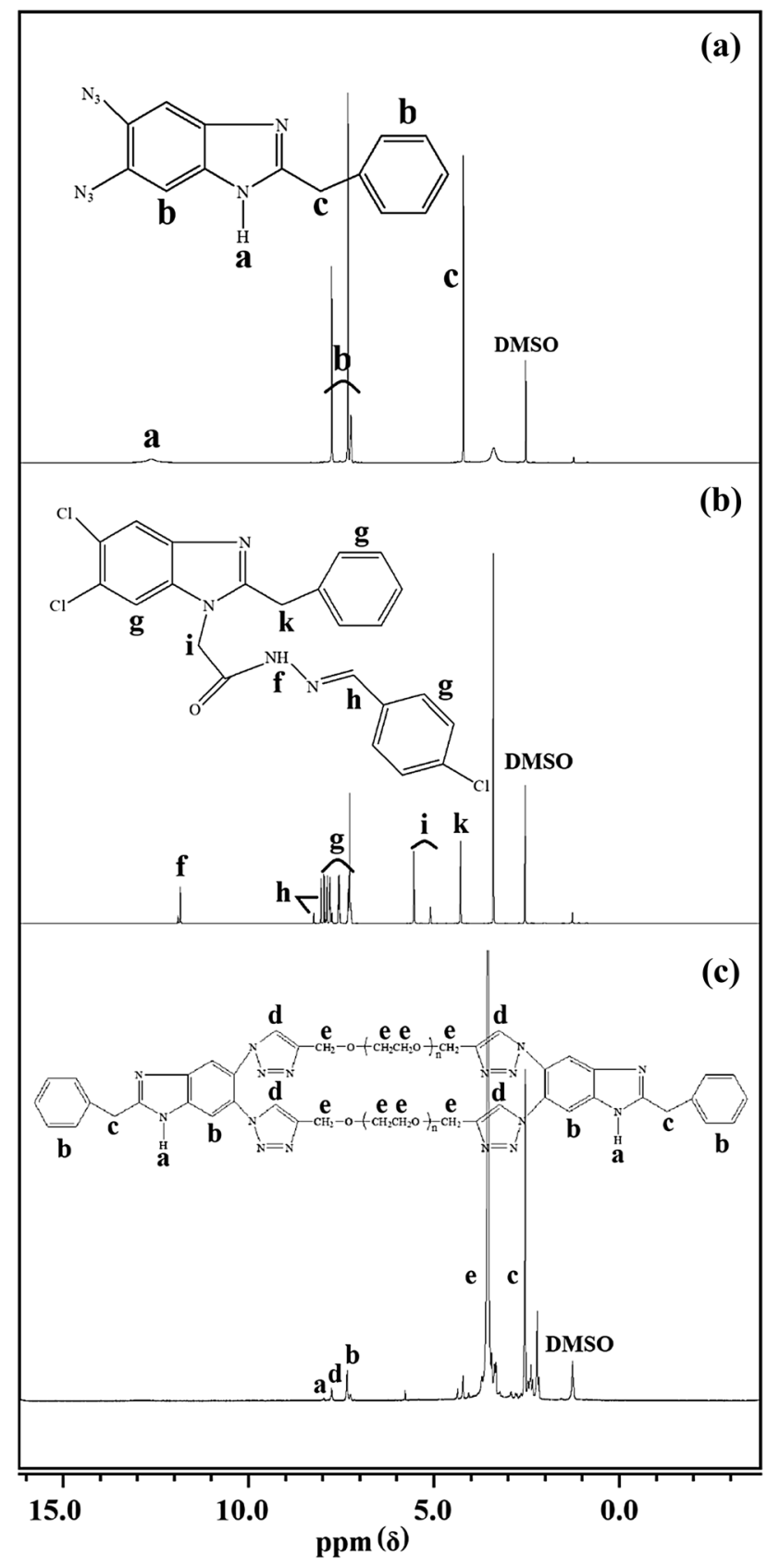

Fig. $1{ }^{1} \mathrm{H}-\mathrm{NMR}$ spectrum of a Di- $\mathrm{N}_{3} ; \mathbf{b}$ Tri-Cl; c ring-type polymers including polyethylene glycol (EH-4 in Table 1)

$-\mathrm{CH}_{2}, 2352 \mathrm{~cm}^{-1}$ for $-\mathrm{CN}, 2102 \mathrm{~cm}^{-1}$ for $-\mathrm{N}_{3}, 1650 \mathrm{~cm}^{-1}$ for $-\mathrm{C}=\mathrm{O}$.

\subsection{Synthesis of ring-type and branched polymers including polyethylene glycols via "click" chemistry}

Ring-type polymers including polyethylene glycols were synthesized at $35^{\circ} \mathrm{C}$ via the "click" chemistry of Di- $\mathrm{N}_{3}$ and PEG-dipropargyl (Table 1). The syntheses were carried out at 24,142 and $168 \mathrm{~h}$. The gravimetric conversion was between 28.24 and $88.33 \mathrm{wt} \%$. The maximum yield of the polymer was acquired using PEG-dipropargyl synthesized using PEG with $1500 \mathrm{~g}$ coded EH-3. The minimum yield of the polymer was acquired using PEG-dipropargyl synthesized using PEG with $3000 \mathrm{~g}$ coded EH-4. Scheme 4 shows the reaction pathway for the ring-type polymer synthesis.

The ${ }^{1} \mathrm{H}-\mathrm{NMR}$ spectrum of the ring-type polymers $(\mathrm{EH}-4$ in Table 1) shown in Fig. 1c displayed peaks at $8.0 \mathrm{ppm}$ for $-\mathrm{N} \underline{\mathrm{H}}, 7.7 \mathrm{ppm}$ for aromatic $-\mathrm{C} \underline{\mathrm{H}}$ of triazole, $7.5 \mathrm{ppm}$ for aromatic $-\mathrm{CH}, 3.5 \mathrm{ppm}$ for $-\mathrm{OC} \underline{\mathrm{H}}_{2}$ of $\mathrm{PEG}, 2.5 \mathrm{ppm}$ for $-\mathrm{C}_{2}$ linked aromatic groups. The peak at $8.0 \mathrm{ppm}$ for aromatic $-\mathrm{CH}$ proton of triazole was evidence that the ring-type polymer was synthesized. The FT-IR spectrum of the ringtype polymers (EH-4 in Table 1) shown in Fig. $2 \mathrm{~d}$ indicates signals at $3394 \mathrm{~cm}^{-1}$ for $-\mathrm{NH}, 2873 \mathrm{~cm}^{-1}$ for aliphatic $-\mathrm{CH}_{2}$, $2352 \mathrm{~cm}^{-1}$ for $-\mathrm{CN}, 1662 \mathrm{~cm}^{-1}$ and $1457 \mathrm{~cm}^{-1}$ for triazole units, $1099 \mathrm{~cm}^{-1}$ for - OC. The peaks at $1662 \mathrm{~cm}^{-1}$ and $1457 \mathrm{~cm}^{-1}$ for triazole units was evidence that the ringtype polymers was obtained. Figure 3 indicates the GPC curves of the polymers (EH-2 in Table 1, EH-3 in Table 1, $\mathrm{EH}-4$ in Table 1, EH-6 in Table 1). Mw values of the polymers were between 1200 and $3115 \mathrm{~g} \cdot \mathrm{mol}^{-1}$. Dispersity values of the polymers are between 1.16 and 1.36. Dispersity values of the polymers were relatively narrow as requested. Increases in the molecular weights of the polymers as compared with these of reactants is consistent with the formation of the polymer.

Thermal analysis of the polymers was carried out by DSC and TGA curves. The ring-type polymers has one main individual Td (Fig. 4). TGA has showed interesting properties of the ring-type polymers indicating continuous weight loss starting from $280{ }^{\circ} \mathrm{C}$ to nearly $390{ }^{\circ} \mathrm{C}$ with a derivative at $355^{\circ} \mathrm{C}$ (Fig. 4a). Tg value of the ring-type polymer (EH- 6 in Table 1) was $13^{\circ} \mathrm{C}$. Tg values were reported in the literature for homo PEG as $-60^{\circ} \mathrm{C}$ [48].

The branched polymers including polyethylene glycols were synthesized at $35^{\circ} \mathrm{C}$ via the "click" chemistry of Tri- $\mathrm{N}_{3}$ and PEG-dipropargyl (Table 2). Scheme 5 shows possible chemical structure of the branched polymer synthesis. The ${ }^{1} \mathrm{H}$-NMR spectrum of the branched polymers (HAT-1 in Table 2) shown in Fig. 5 displayed peaks at 7.9 ppm for $-\mathrm{N} \underline{\mathrm{H}}, 7.3 \mathrm{ppm}$ for aromatic $-\mathrm{C} \underline{\mathrm{H}}$ of triazole, $4.7 \mathrm{ppm}$ for $-\mathrm{N}=\mathrm{CH}_{1}, 4.0 \mathrm{ppm}$ for $-\mathrm{NC}_{2}, 3.5 \mathrm{ppm}$ for $-\mathrm{OC}_{\underline{2}}$ of PEG unit, $1.3 \mathrm{ppm}$ aliphatic $-\mathrm{C}_{2}$. The syntheses were carried out at $93 \mathrm{~h}$. The gravimetric conversion was between 40.71 and $77.86 \mathrm{wt} \%$. The maximum yield of the polymer was acquired using PEG-dipropargyl synthesized using PEG with $1500 \mathrm{~g}$ coded HAT-4. The minimum yield of the polymer was acquired using PEG-dipropargyl synthesized using PEG with $600 \mathrm{~g}$ coded HAT-2. Mw values of the polymers were between 1036 and $3145 \mathrm{~g} \cdot \mathrm{mol}^{-1}$. Dispersity values of the polymers are between 1.11 and 1.32. The 

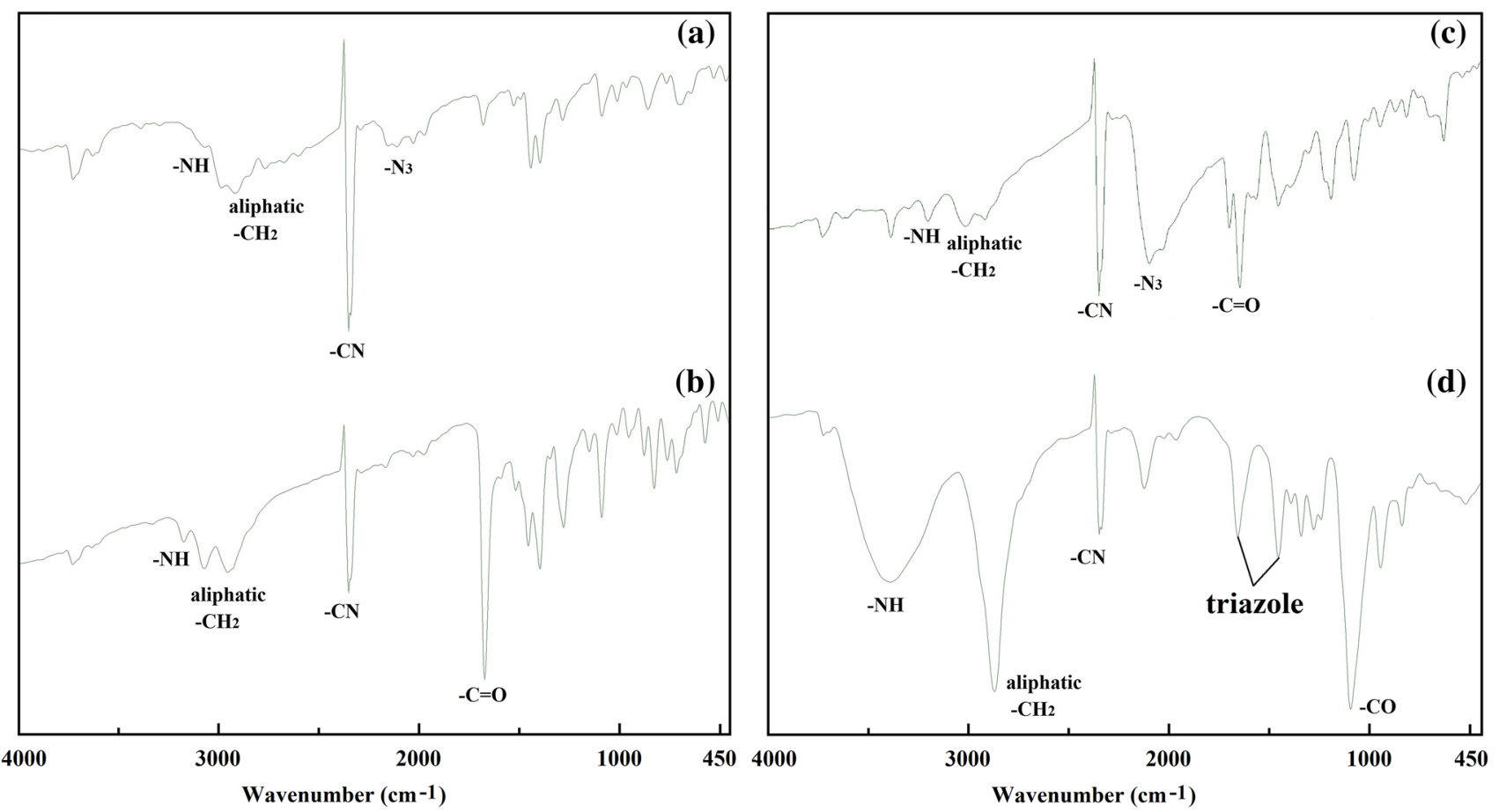

Fig. 2 FT-IR spectrum of a Di- $\mathrm{N}_{3} ; \mathbf{b}$ Tri-Cl; $\mathbf{c}$ Tri- $\mathrm{N}_{3} ; \mathbf{d}$ ring-type polymers including polyethylene glycol (EH-4 in Table 1)

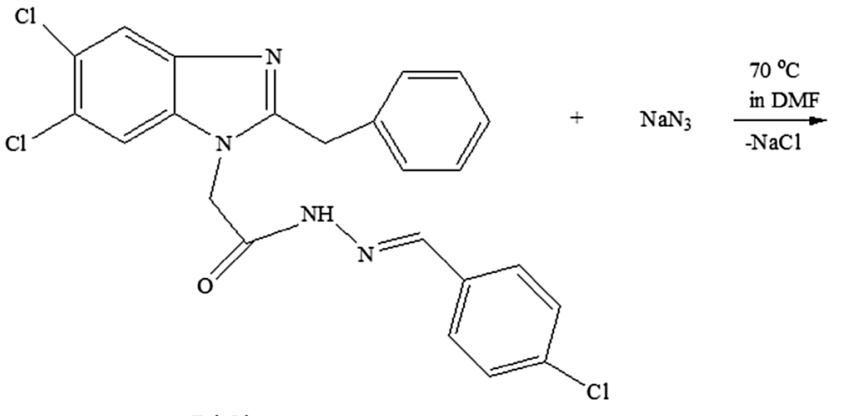

Tri-C1

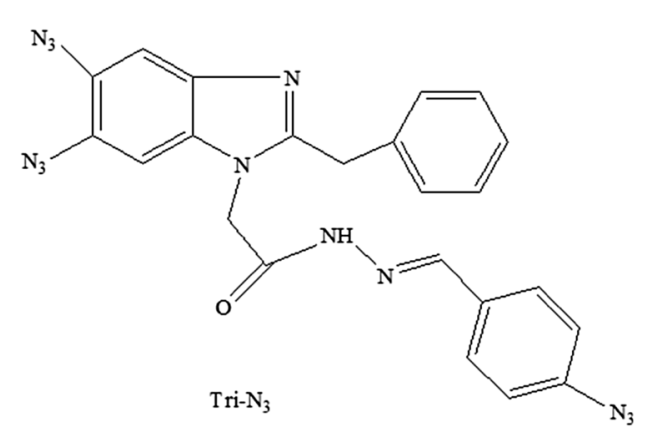

Scheme 3 Reaction pathways in the synthesis of Tri- $\mathrm{N}_{3}$

$\mathrm{HC} \equiv \mathrm{CCH}_{2}-\mathrm{O}-\mathrm{CH}_{2} \mathrm{CH}_{2} \mathrm{O} \frac{1}{\mathrm{in}} \mathrm{CH}_{2} \mathrm{C} \equiv \mathrm{CH}+$<smiles>CCOCCN</smiles>

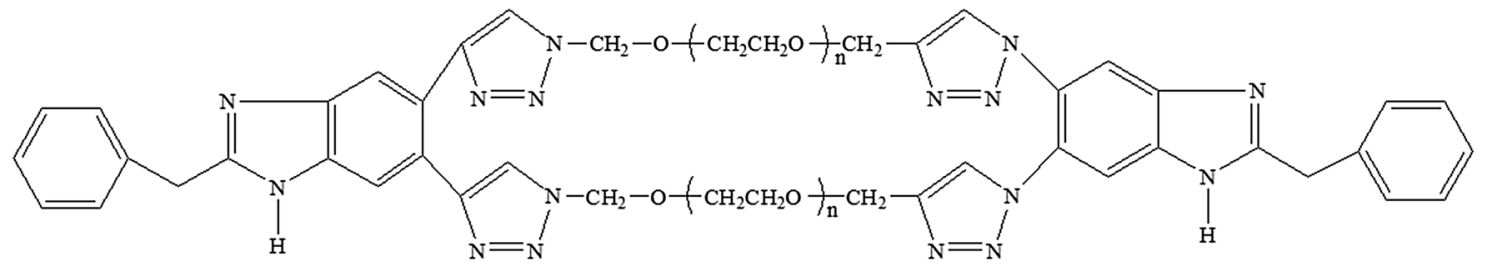

Scheme 4 Reaction outline for synthesis of ring-type polymers including polyethylene glycols 

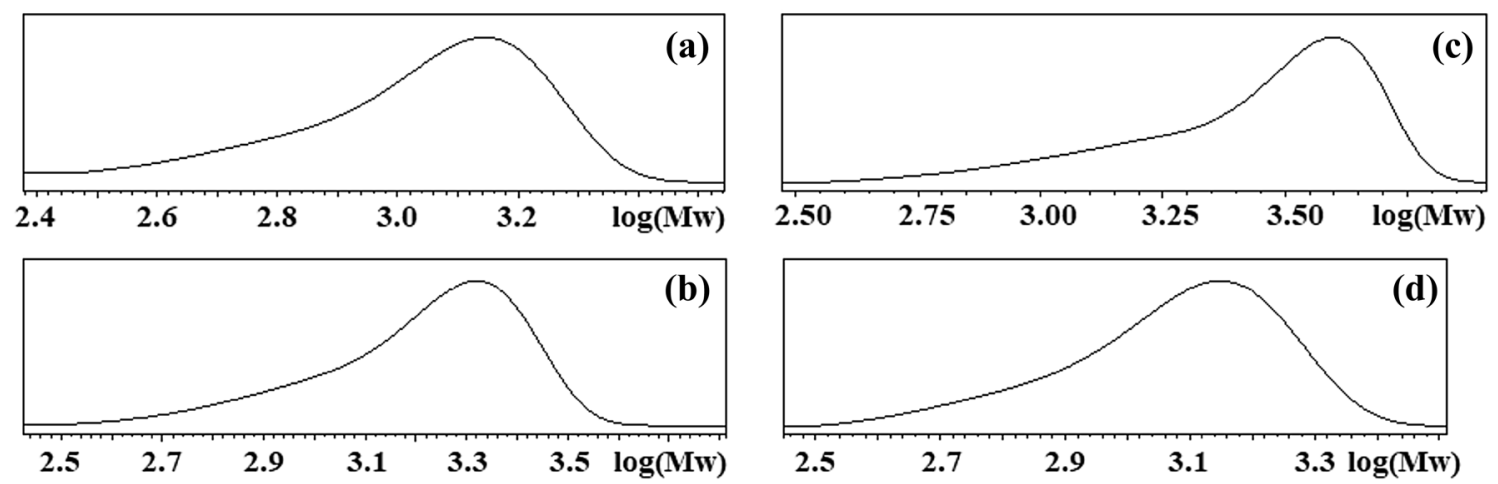

Fig. 3 GPC curves of the ring-type polymers: a EH-2 in Table 1; b EH-3 in Table 1; c EH-4 in Table 1; d EH-6 in Table 1
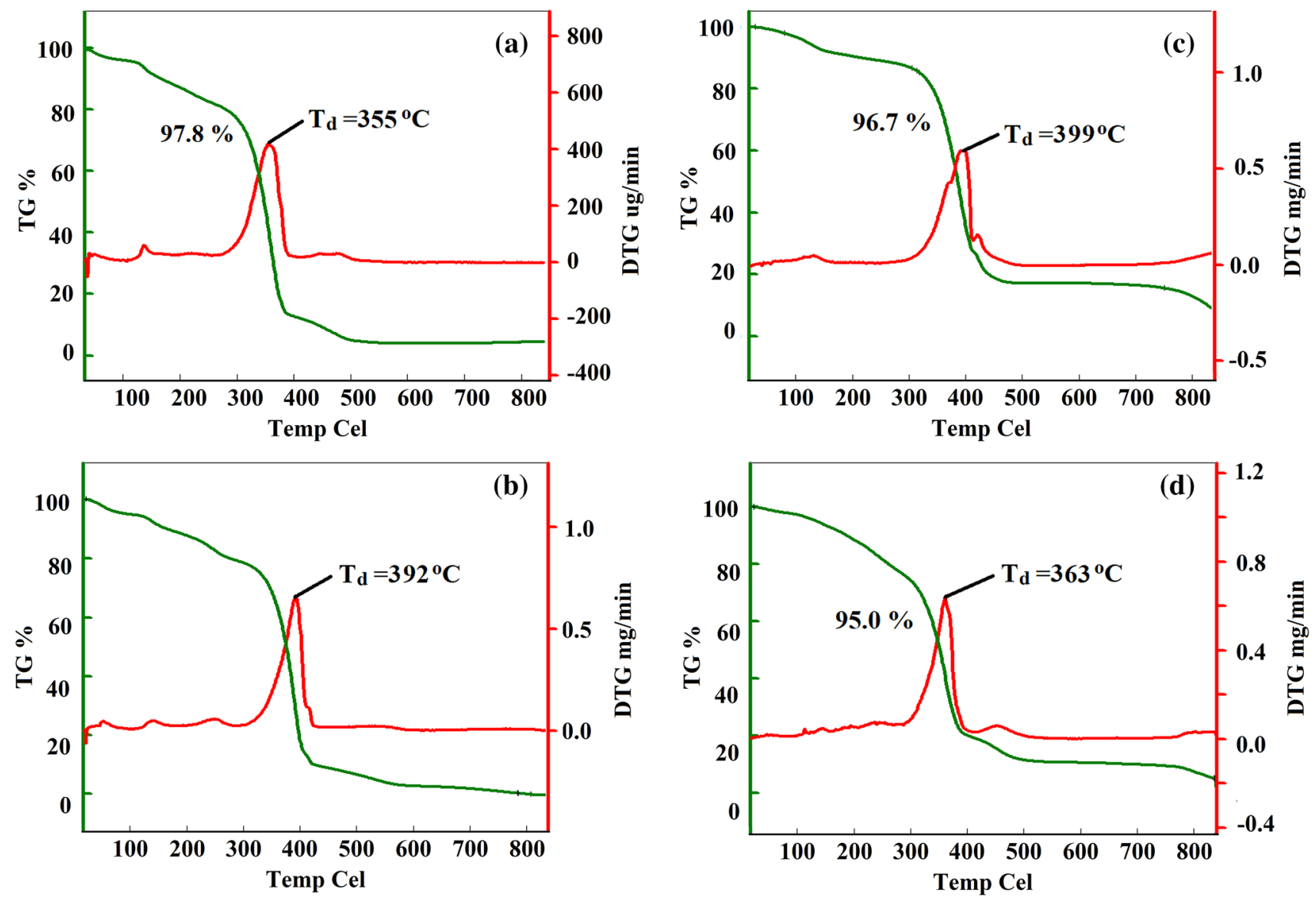

Fig. 4 TGA curves of the polymers: a EH-2 in Table 1; b EH-3 in Table 1; c EH-4 in Table 1; d HAT-5 in Table 2

branched polymers have one main individual Td (Fig. 4d). TGA has showed interesting properties of the branched polymers indicating continuous weight loss starting from $300^{\circ} \mathrm{C}$ to nearly $400^{\circ} \mathrm{C}$ with a derivative at $363^{\circ} \mathrm{C}$ (Fig. 4 d).
One main individual Td of the polymers can be attributed to the high miscibility of the polymerizable propargyl groups of PEG-dipropargyl with moieties of Di- $\mathrm{N}_{3}$ and Tri- $\mathrm{N}_{3}$. 


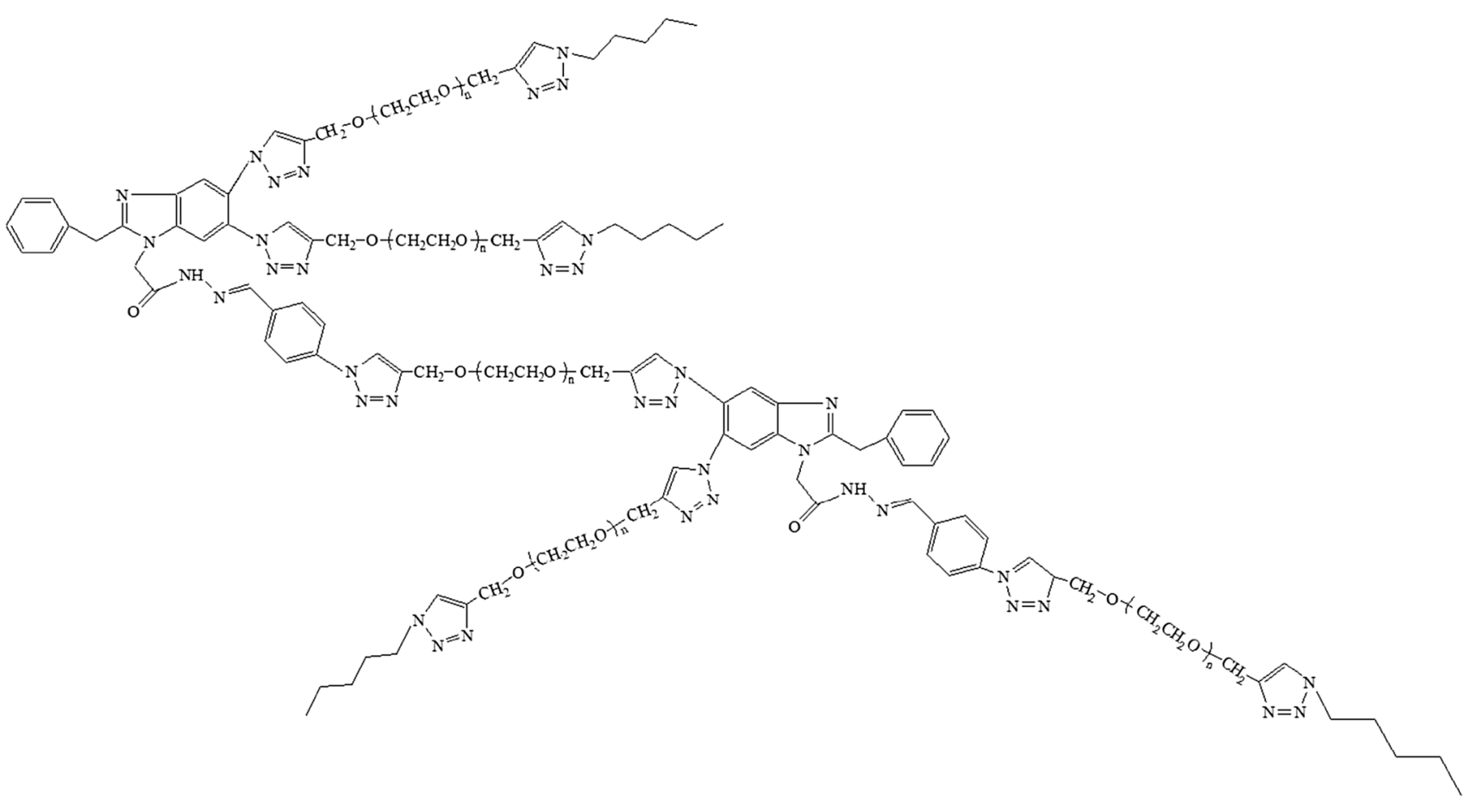

Scheme 5 Chemical structure of the branched polymer including polyethylene glycols

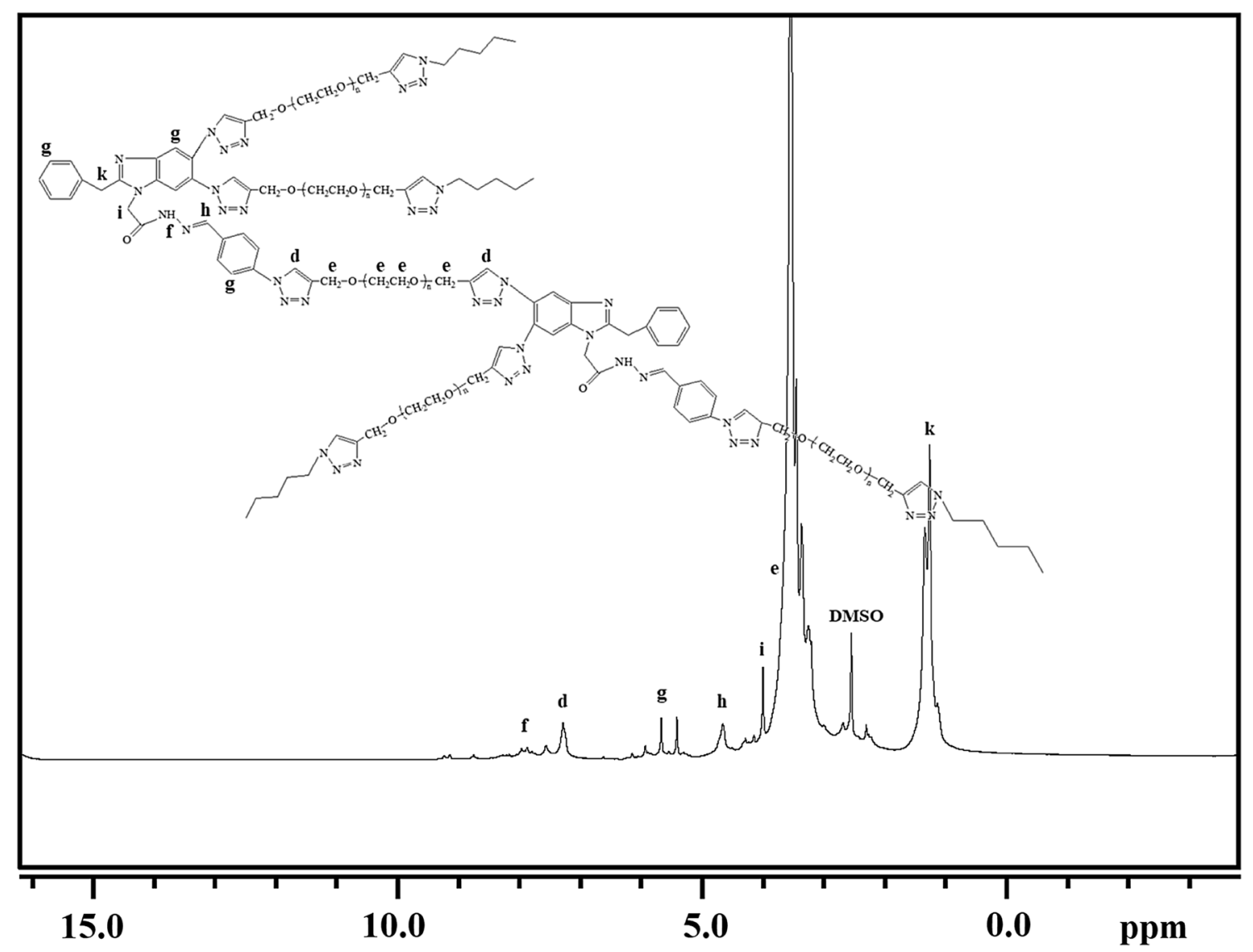

Fig. $5{ }^{1} \mathrm{H}$-NMR spectrum of the branched polymers including polyethylene glycol (HAT-1 in Table 2)

\section{SN Applied Sciences}




\section{Conclusions}

The "click" chemistry synthesis of ring-type and branched polymers including polyethylene glycols was acquired. The polymers were obtained in high yield and low dispersities. This method for synthesis of polymer including benzimidazole ring is simple and efficient. Products characterization was done using multi instruments. This study can provide new, well-characterized materials with wide biomedical application potential through the polymers including PEG and benzimidazole rings.

Funding The work was founded by Giresun University Scientific Research Fund (Grand Number: FEN-BAP-A-230218-28).

\section{Compliance with ethical standards}

Conflict of interest The authors declare that they no competing interests.

\section{References}

1. Kolb HC, Finn MG, Sharpless KB (2001) Click chemistry: diverse chemical function from a few good reactions. Angew Chem Int Ed 40:2004-2021. https://doi.org/10.1002/1521-3773(20010 601)40:11\%3c2004:AID-ANIE2004\%3e3.0.CO;2-5

2. Moses JE, Moorhouse AD (2007) The growing applications of click chemistry. Chem Soc Rev 36:1249-1262. https://doi. org/10.1039/B613014N

3. Zhu DY, Cao GS, Qiu WL, Rong MZ, Zhang MQ (2015) Selfhealing polyvinyl chloride (PVC) based on microencapsulated nucleophilic thiol-click chemistry. Polymer 69:1-9. https://doi. org/10.1016/j.polymer.2015.05.052

4. Balasubramanian R, Kumutha K, Sarojadevi M (2016) Mechanical, thermal and electrical properties of polyimides containing 1, 2, 3-triazole ring prepared by click reaction. Polym Bull 73:309-330. https://doi.org/10.1007/s00289-015-1488-z

5. Xu J, Ye J, Liu SY (2007) Synthesis of well-defined cyclic poly(Nisopropylacrylamide) via click chemistry and its unique thermal phase transition behavior. Macromolecules 40:9103-9110. https ://doi.org/10.1021/ma0717183

6. Yuan W, Huang W, Zou H (2016) Synthesis and properties of $\mathrm{CO}_{2}$-responsive copolymer by the combination of reversible addition fragmentation chain transfer polymerization and click chemistry. Polym Bull 73:2199-2210. https://doi. org/10.1007/s00289-016-1603-9M

7. Tunca U (2013) Triple click reaction strategy for macromolecular diversity. Macromol Rapid Commun 34:38-46. https://doi. org/10.1002/marc.201200656

8. Altıntas O, Tunca U (2011) Synthesis of terpolymers by click reactions. Chem-An Asian J 6:2584-2591. https://doi. org/10.1002/asia.201100138

9. Parrish B, Breitenkamp RB, Emrick T (2005) PEG- and peptidegrafted aliphatic polyesters by click chemistry. J Am Chem Soc 127:7404-7410. https://doi.org/10.1021/ja050310n

10. Şanal T, Koçak I, Hazer B (2017) Synthesis of comb-type amphiphilic graft copolymers derived from chlorinated poly( $\varepsilon$-caprolactone) via click reaction. Polym Bull 74:977-995. https://doi.org/10.1007/s00289-016-1757-5

11. Xi W, Scott TF, Kloxin CJ, Bowman CN (2014) Click chemistry in materials science. Adv Funct Mater 24:2572-2590. https://doi. org/10.1002/adfm.201302847

12. Öztürk T, Meyvacı E (2017) Synthesis and characterization poly( $\varepsilon$-caprolactone-b-ethylene glycol-b- $\varepsilon$-caprolactone) ABA type block copolymers via "click" chemistry and ring-opening polymerization. J Macromol Sci Part A Pure Appl Chem 54:575581. https://doi.org/10.1080/10601325.2017.1309251

13. Enomoto-Rogers Y, Iwata T (2012) Synthesis of xylan-graftpoly(L-lactide) copolymers via click chemistry and their thermal properties. Carbohydr Polym 87:1933-1940. https://doi. org/10.1016/j.carbpol.2011.09.092

14. Wu Q, Yi J, Wang S, Liu D, Song X, Zhang G (2015) Synthesis and self-assembly of new amphiphilic thermosensitive poly $(\mathrm{N}$ vinylcaprolactam)/poly ( $D$, L-lactide) block copolymers via the combination of ring-opening polymerization and click chemistry. Polym Bull 72:1449-1466. https://doi.org/10.1007/s0028 9-015-1348-x

15. Binder WH, Sachsenhofer R (2007) 'Click' chemistry in polymer and materials science. Macromol Rapid Commun 28:15-54. https://doi.org/10.1002/marc.200600625

16. Öztürk T, Kayğın O, Göktaş M, Hazer B (2016) Synthesis and characterization of graft copolymers based on polyepichlorohydrin via reversible addition-fragmentation chain transfer polymerization. J Macromol Sci Part A Pure Appl Chem 53:362-367. https ://doi.org/10.1080/10601325.2016.1166002

17. Göktaş M, Öztürk T, Atalar MN, Tekeş AT, Hazer B (2014) Onestep synthesis of triblock copolymers via simultaneous reversible-addition fragmentation chain transfer (RAFT) and ringopening polymerization using a novel difunctional macro-raft agent based on polyethylene glycol. J Macromol Sci Part A Pure Appl Chem 51:854-863. https://doi.org/10.1080/10601 325.2014.953366

18. ÖztürkT, Yavuz M, Göktaș M, Hazer B (2016) One-step synthesis of triarm block copolymers by simultaneous atom transfer radical and ring-opening polymerization. Polym Bull 73:1497-1513. https://doi.org/10.1007/s00289-015-1558-2

19. Öztürk T, Göktaş M, Savaş B, Işıklar M, Atalar MN, Hazer B (2014) Synthesis and characterization of poly(vinylchloride-graft2-vinylpyridine) graft copolymers using a novel macroinitiator by reversible addition-fragmentation chain transfer polymerization. e-Polymers 14:27-34. https://doi.org/10.1515/epoly $-2013-0011$

20. Öztürk T, Göktaş M, Hazer B (2010) One-step synthesis of triarm block copolymers via simultaneous reversible-addition fragmentation chain transfer and ring-opening polymerization. J Appl Polym Sci 117:1638-1645. https://doi.org/10.1002/ app.32031

21. ÖztürkT, Atalar MN, Göktaş M, Hazer B (2013) One-step synthesis of block-graft copolymers via simultaneous reversible-addition fragmentation chain transfer and ring-opening polymerization using a novel macroinitiator. J Polym Sci Part A Polym Chem 51:2651-2659. https://doi.org/10.1002/pola.26654

22. Hadjichristidis N, latrou H, Pitsikalis M, Mays J (2006) Macromolecular architectures by living and controlled/living polymerizations. Prog Polym Sci 31:1068-1132. https://doi.org/10.1016/j. progpolymsci.2006.07.002

23. Deffieux A, Schappacher M (1999) Synthesis and characterization of star and comb polystyrenes using isometric poly(chloroethyl vinyl ether) oligomers as reactive backbone. Macromolecules 32:1797-1802. https://doi.org/10.1021/ma981 $612 \mathrm{v}$ 
24. Velichkova RS, Christova DC (1995) Amphiphilic polymers from macromonomers and telechelics. Prog Polym Sci 20:819-887. https://doi.org/10.1016/0079-6700(95)00004-Y

25. Riess G (2003) Micellization of block copolymers. Prog Polym Sci 28:1107-1170. https://doi.org/10.1016/S0079-6700(03)00015-7

26. Gacal B, Durmaz H, Tasdelen MA, Hizal G, Tunca U, Yagci Y, Demirel AL (2006) Anthracene-maleimide-based Diels-Alder "click chemistry" as a novel route to graft copolymers. Macromolecules 39:5330-5336. https://doi.org/10.1021/ma060690c

27. Pispas S, Hadjichristidis N (2003) Aggregation behavior of poly(butadiene-b-ethylene oxide) block copolymers in dilute aqueous solutions: effect of concentration, temperature, ionic strength, and type of surfactant. Langmuir 19:48-54. https:// doi.org/10.1021/la020561z

28. Öztürk T, Hazer B (2010) Synthesis and characterization of a novel macromonomer initiator for reversible addition fragmentation chain transfer (RAFT). Evaluation of the polymerization kinetics and gelation behaviors. J Polym Sci Part A Polym Chem 47:265-272

29. Öztürk T, Göktaş M, Hazer B (2011) Synthesis and characterization of poly(methyl methacrylate-block-ethylene glycolblock-methyl methacrylate) block copolymers by reversible addition fragmentation chain transfer polymerization. $J$ Macromol Sci Part A Pure Appl Chem 48:65-70. https://doi. org/10.1080/10601325.2011.528310

30. Asan N, Öztürk T (2017) Synthesis and characterization of poly (vinyl chloride-graft-ethylene glycol) graft copolymers by "click" chemistry. Hacet J Biol Chem 45:35-42. https://doi. org/10.15671/HJBC.2017.139

31. Öztürk T, Ayyıldız H, Meyvacı E, Göktaş M (2017) Synthesis and characterization of poly (epichlorohydrin-graft-ethylene glycol) graft copolymers by "click" chemistry. Karaelmas Fen ve Mühendislik Dergisi 7:47-54

32. Hazer B (2010) Amphiphilic poly(3-hydroxy alkanoate)s: potential candidates for medical applications. Int J Polym Sci 2010:423460. https://doi.org/10.1155/2010/423460

33. Erciyes AT, Erim M, Hazer B, Yağcı Y (1992) Synthesis of polyacrylamide flocculants with poly(ethylene glycol) segments by redox polymerization. Angew Macromol Chem 200:163-171

34. Öztürk T, Cavicchi CA (2018) Synthesis and characterization of poly(epichlorohydrin-g- $\varepsilon$-caprolactone) graft copolymers by "click" chemistry. J Polym Mater 35:209-220

35. Stevenson C, Davies RJH (1999) Photosensitization of guaninespecific DNA damage by 2-phenylbenzimidazole and the sunscreen agent 2-phenylbenzimidazole-5-sulfonic acid. Chem Res Toxicol 12:38-45. https://doi.org/10.1021/tx980158|

36. Kahveci B, Karaali N, Yılmaz F, Menteşe E (2014) An efficient synthesis of some new bisbenzimidazoles via microwave technique. Turk J Chem 38:429-723. https://doi.org/10.3906/kim-1305-17
37. Sierra-Zenteno A, Galan-Vidal CA, Tapia-Benavides R (2002) Acidbase equilibrium studies of 2-(aminomethyl)benzimidazole in aqueous solution. J Mex Chem Soc 46:125-130

38. Utku S, Topal M, Dogan A, Serin MS (2010) Synthesis, characterization, antibacterial and antifungal evaluation of some new platinum(II) complexes of 2-phenylbenzimidazole ligands. Turk J Chem 34:427-436. https://doi.org/10.3906/kim-1002-5

39. Menteşe E, Yılmaz F, Emirik M, Ülker S, Kahveci B (2018) Synthesis, molecular docking and biological evaluation of some benzimidazole derivatives as potent pancreatic lipase inhibitors. Bioorg Chem 76:478-486. https://doi.org/10.1016/j.bioor g.2017.12.023

40. Grimmett MR (2002) In: Neier R, Bellus D (ed) Science of synthesis. Thieme, New York, vol 12, p 529. https://doi.org/10.1055/ sos-sd-012-00002

41. Velik J, Baliharova V, Fink-Gremmels J, Bull S, Lamka J, Skalova $L$ (2004) Benzimidazole drugs and modulation of biotransformation enzymes. Res Vet Sci 76(2):95-108. https://doi. org/10.1016/j.rvsc.2003.08.005

42. Kohler $P(2001)$ The biochemical basis of anthelmintic action and resistance. Int J Parasitol 31:336-345. https://doi.org/10.1016/ S0020-7519(01)00131-X

43. Maurya MR, Bharti N (1999) Synthesis, thermal and spectral studies of oxoperoxo and dioxo complexes of vanadium $(\mathrm{V})$, molybdenum( $\mathrm{VI})$ and tungsten $(\mathrm{VI})$ with 2-(a-hydroxyalkyl/ aryl)benzimidazole. Transit Met Chem 24:389-393. https://doi. org/10.1023/A:1006942231677

44. Menteşe E (2013) Efficient microwave assisted synthesis of some new benzimidazoles containing the mebendazole nucleus. J Chem Res 37:168-170. https://doi.org/10.3184/174751913X 13603595770952

45. Kantar GK, Menteşe E, Beriş FŞ, Şaşmaz S, Kahveci B (2018) Synthesis and antimicrobial activity of some new triazole bridged benzimidazole substituted phthalonitrile and phthalocyanines. Rev Roum Chim 63:59-65

46. Aries R: Fr. Demande (1972) FR 2104717-19720526

47. Kahveci B, Menteşe E, Özil M, Ertürk M (2013) An efficient synthesis of benzimidazoles via a microwave technique and evaluation of their biological activities. Monatsh Chem 144:993-1001. https ://doi.org/10.1007/s00706-012-0916-0

48. Törmälä $P$ (1974) Determination of glass transition temperature of poly(ethylene glycol) by spin probe technique. Eur Polym J 10(6):519-521

Publisher's Note Springer Nature remains neutral with regard to jurisdictional claims in published maps and institutional affiliations. 